\title{
HAJJ PILGRIMS' ABANDONMENT: THE PROTECTION FOR CONSUMER (CASE OF PT ANUGRAH KARYA WISATA UTAMA AND PT ABU TOURS \& TRAVEL)
}

\author{
Sekar Arum Rahmawati ${ }^{1 凶}$ \\ 1 Universitas Jabal Ghafur, Sigli, Aceh, Indonesia \\ $\bowtie$ sekararum9898@gmail.com
}

\section{CITED AS}

Rahmawati, S. A. (2021). Hajj Pilgrims' Abandonment: The Protection for Consumer (Case of PT Anugrah Karya Wisata Utama and PT Abu Tours \& Travel). Journal of Law and Legal Reform,2(4), 481-492. https://doi.org/10.15294/jllr.v2i4.48764

Submitted: December 7, $2020 \quad$ Revised: March 11, $2021 \quad$ Accepted: July 11, 2021

\section{ABSTRACT}

People are encouraged to selectively choose a trusted umroh travel agency. First Travel and Abu Travel has violated Article 65 letter a Government Regulation Number 79 Year 2012 on Implementation of Law Number 13 Year 2008 regarding Hajj Implementation. The violation is a neglect of Umrah pilgrims who failed to leave for Saudi Arabia and resulted in material and immaterial losses experienced by Umrah congregation. The type of legal research used by the authors in this study is the type of legal case study research; This type of research is also called Library Research, is research conducted by tracing or reviewing and analyzing library materials or materials ready to use documents. Improving the supervision of umrah. The supervision is done because it can increase the travel agency of umroh and haj pilgrimage, so that with this supervision the prospective pilgrims who register will not get the act of fraud.

Keywords: Legal Protection; Consumer Protection; Fraud 


\section{INTRODUCTION}

The amount of news about fraud by umroh travel agency makes people feel afraid and feel disadvantaged both morally and materially. People are encouraged to selectively choose a trusted umroh travel agency. The fraternity of Indonesian Umrah Hajj Entrepreneurs (Perpuhi) reminds people not to be tempted by the umroh package with the cost that is too cheap because from year to year there is always a case of Umroh fraud. The following is the databases of fraud cases that occurred in Indonesia. This can be proven as follows:

1. In 2015 there are 1,610 number of Umrah pilgrims who are victims of Hajj and Umrah fraud cases.

2. In 2016 record 290 number of pilgrims who become victims of fraud cases 3

3. In the year 2017 recorded 35,149 number of Umrah pilgrims who became victims of the case of hajj and Umrah scams.

The crime of fraud including "materieel delict" means that its perfection must be a result. As set forth in the Second Book of Chapter XXV Article 378 of the Criminal Code, namely: Anyone with the intent to benefit himself or others against the law, by using false or false dignity, by trickery or by a series of lies moving others to surrender something to him, or to lend to a debt or to waive a receivable, be threatened for fraud with a maximum imprisonment of 4 (four) years.

This fraud policy is inseparable from the broader policy, which is a social policy consisting of policies or efforts to protect the community. Crime prevention in essence is an integral protection of society. Therefore, it can be said that the ultimate goal or the main goal of crime prevention is the protection of society to achieve the welfare of the community. Law is the whole code of conduct prevailing in a collective life that can be imposed with a sanction. Implementation of the law can take place formally and peacefully but can also occur due to violations of the law should be enforced.

As a Customer of Consumer Protection rights, Consumer Protection is any user of goods or services available in the community, whether for self-interest, family, other people, or other living beings and not to be traded 'While the Economic Dictionary gives the consumer as a person who enjoys the physical use of an economic object or economic service2. While the rights owned by consumers as listed in Law No. 8 of 1999 About Consumer Protection is:

a) the right to comfort, safety and safety in consuming goods and or services;

b) the right to choose goods and or services and to obtain the goods and or services in accordance with the exchange rate and the conditions and promised warranties;

c) the right to true, clear, and truthful information about the condition and guarantee of goods and or services;

d) the right to be heard of his opinions and complaints on goods and / or services used; 
e) the right to appropriate advocacy, protection, and dispute resolution efforts;

f) the right to education and consumer education

g) the right to be treated or served properly and honestly and nondiscriminatively (Salim, 2004).

Before the era of the 1995s, the sale of Umrah services was done conventionally that consumers came to an Umrah travel agency and filled out the registration form and deposited a sum of money as the Umrah registration fee in accordance with the travel package desired by consumers along with other administrative requirements. But in recent years the trip of Umrah PT. First Travel Anugrah Karya Wisata and followed by Abu Travel began to disturb the community and harming consumers who need the existence of examination and protection of Umrah and Hajj worship is the duty of the Ministry of Religious Affairs in accordance with the Regulation of the Minister of Religious Affairs Number 18 of 2015 Article 20 Paragraph (1) and Paragraph (2) stating that:

1) Conducting examination and protection by a Director-General on behalf of the Minister.

2) The examination as referred to in paragraph (1) shall include supervision of travel plans, operational activities of Jemaah service, obedience and / or disciplinary to the provisions of legislation.

In the year 2017, re-going umrah "naughty" travel agency which is currently in the spotlight of the Travel Bureau Umrah PT. First Anugerah Karya Wisata (First Travel) and Abu Tours and Travel. Owners of First Travel and Abu Tours and Travel are alleged to have committed criminal fraud, embezzlement, and money laundering by the umrah mode.

Associated with the case of First Travel and Abu travel, Over time, their career in the business travel umrah worship experienced a fairly rapid development. Characterized by several awards they receive, one of which is the award of the Record Museum Indonesia (MURI) for the holding of Manasik Umrah Akbar which was attended by 35 thousand pilgrims on 1 November 2014. The price offered by First Travel seems indeed successful to attract much interest of pilgrims to entrust their Umrah trip in this travel. First Travel and Abu Travel allegedly committed fraud by offering a very cheap umrah promo package of Rp14.3 million for regular packages and Rp 54 million for VIP packages. Umrah promo package is successfully attracted many prospective pilgrims. The number of candidates registered at First Travel reached 72,672 people. But most of the pilgrims failed to leave Umrah, with a total loss of Rp848.7 billion. From December 2016 to May 2017, First Travel was only able to dispatch 14,000 worshipers, while 58,682 other pilgrims were losers. The prospective pilgrims who are losers are reporting to the crisis center Criminal Investigation Police. Total rapporteurs reached 4,043 people. There are other reports submitted via email of 2,280 reports (Anggrianto, 2002).

In the case of Umrah fraud by First Travel and Abu Travel, the pilgrims are promised to get Umrah facility class VIP with umrah fee of only Rp14, 3 million. 
The cost is far below the minimum standard cost of umrah set by the Muslim Association of Hajj and Umrah RI (AMPHURI) and Ministry of Religious Affairs, which is 1,700 USD or equivalent to Rp22.61 million per person. The difference in cost of Rp8, 31 million is not obtained from the profits of the company but covered with money collected from the Umrah pilgrims of the next period. First Travel and Abu Travel deliberately dispatched the congregation in small numbers so that there is a grace period to be able to use the money to dispatch pilgrims who first register.

The loss of candidate for Umrah pilgrims reached Rp 839.12 billion. That figure does not include the Rp2.5 million surcharge that First Travel requested in May under the pretext of a charter aircraft fee. First Travel also offers Ramadan package at an additional cost of Rp 3 million to Rp 8 million per pilgrim. The total loss of pilgrims on this pretext reached Rp9.54 billion. Not only harming pilgrims, Police Bareskrim has also received debt complaints amounting to Rp9, 7 billion First Travel and Abu Travel to visa providers, three hotels in Mecca and three hotels in Madinah with a total of Rp24 billion, as well as to airline ticket provider of Rp85 billion.

Some price packages provided by them, among others, Umrah Phenomenal dibanderol with the price of Rp 13.5 million for the journey of 9 days and Regular Umrah priced of Rp 25 million for 9 days journey. With a growing business, First Travel and Abu Travel successfully lure famous names to use their services as umrah religious travel agencies. Newest celebrities in the country, such as Syahrini who use the services First Travel to leave Umrah. In addition, First Travel is known for the departure of a considerable number of pilgrims each year. that First travel and Abu Travel will dispatch 50 thousand pilgrims in 2017. But just a few months running in 2017, First Travel reportedly having problems in this March. The pilgrims who were supposed to leave in May of 2017 were postponed and have not been confirmed. Some pilgrims have paid off from the previous two years. To this day, dozens of pilgrims come to the First Travel office in Depok and on TB Road. Simatupang Jaksel to ask for certainty (Widjaya, 2008).

Revocation of such permit because the sale of promo Umrah First Travel and Abu Travel is disturbing all the community. First Travel always break the promise to dispatch pilgrims. Previously the Ministry of Religious Affairs (Kemenag) revoked the permit for the implementation of Umrah worship trip of PT First Anugerah Karya Wisata (First Travel). Revocation of First Travel and Abu Travel permit is stated in Decree of Minister of Religious Affairs Number 589 Year 2017 concerning Elimination of Administration Sanction Revocation of License for Implementation of PT First Anugerah Karya Wisata as the Implementation of Umrah Worship Travel the Ministerial Decree has been effective since August 1, 2017.

The Ministry of Religious Affairs (Kemenag) affirmed the travel agent company First Travel and Abu Travel obliged to refund the funds already paid. although his license has been revoked, that does not mean eliminating First 
Travel's obligations to his congregation. They are still obliged to return the entire cost of Umrah pilgrims who have registered or delegate all Umrah pilgrims who have signed up to other PPIU without adding any cost (Miru \& Yudo, 2015).

First Travel and Abu Travel has violated Article 65 letter a Government Regulation Number 79 Year 2012 on Implementation of Law Number 13 Year 2008 regarding Hajj Implementation. The violation is a neglect of Umrah pilgrims who failed to leave for Saudi Arabia and resulted in material and immaterial losses experienced by Umrah congregation. Chaotic umrah administration by First Travel began to rise when the failure of the departure of pilgrims on March 28, 2017, ago. The existence of the above problems has attracted the author's interest to examine through research with the title: "Hajj Pilgrims' Abandonment: The Protection for Consumer (Case of PT Anugrah Karya Wisata Utama and PT Abu Tours \& Travel)" (Rokhmad, 2016).

\section{METHOD}

The type of legal research used by the authors in this study is the type of legal case study research; This type of research is also called Library Research, is research conducted by tracing or reviewing and analyzing library materials or materials ready to use documents. In legal research this form is known as Legal Research, and the type of data obtained is called secondary data. Activities undertaken may take the form of tracking and analyzing regulations, collecting and analyzing verdict or jurisprudence, reading and analyzing contracts or searching, reading and making summaries of reference books. This type of activity is commonly done in normative legal research or doctrinal law research form research by studying literature studies, often also called library research or document studies such as Laws, books, referred to as Legal Research.

The nature of the research used in this study is Descriptive Research Analyst, namely research that describes the criminal acts of fraud and or embezzlement. This is intended to provide a systematic and comprehensive overview that can help reinforce theories of fraud and / or embezzlement.

The type of data viewed from the source, can be distinguished between data to be obtained directly from the community and data obtained from library materials. Data obtained from legislation8 include: The Criminal Code Furthermore called the Criminal Code, Law No. 8 of 1981 on the Law Criminal Procedure Law, Law Number 13 Year 2008 concerning the Implementation of Hajj. Secondary law materials, namely legal materials that provide explanations about the primary legal materials such as those derived from the work of law scholars, journals, and literature books that can be used as a reference in this study. While tertiary legal materials are materials that provide guidance and explanation of primary and secondary legal materials, such as dictionaries, legal encyclopedias and other supporting facilities (Muhammad, 2004). 


\section{CASE OVERVIEW}

Andika Surachman and Anniesa Hasibuan were founders of the First Travel travel bureau. In the past before the start of business by establishing First Travel, Andika was an apprentice employee of a private bank with paid salary per day. Then he continued his career as a minimart employee. When his father-in-law died and had to support his three younger sisters-in-law. This is what makes Andika start a business such as establishing kios pulsa, selling burgers and bed linen. But losses and owed 50 million, so must submit the house of his father-inlaw is used as collateral and only the remaining money of 10 million. The money is used Andika to open CV First Karya Utama which is engaged in the field of travel agency. Andika and his wife started this business with their dreams who want to travel around Indonesia even though they have no experience in the field at all. Enterprises began to show results when receiving 100 clients from Bank Indonesia to umroh and win the tender from Pertamina. CV First Karya Utama changed to PT First Travel and finally began to get many clients, especially prospective pilgrims umroh. In 2012 it managed to increase 800-900 people, the next year increased to 3600 people, in 2014 dispatched 15700 people and by the year 2016 there are already 35,000 who will be dispatched to the holy land. Because often cheated by his friend andika not lifting employees again from people they know and open canang to London. Now First Travel became one of the leading travel agencies with a turnover of 30 million US dollars (Arifin, Wahyuningsig, \& Kusriyah, 2017). Here is a case chronology:

1. July 1, 2009 First travel started his business from a travel agency business, under CV First Karya Utama. Offers domestic and international tour services for both individual and corporate clients.

2. Early 2011 penetrated umroh religious travel business under the banner of PT First Anugerah Karya Wisata and developed rapidly March 28, 2017 First Travel received attention Kemenag after First Travel failed to dispatch Umrah congregation. In that event pilgrims lodged in hotels around Soekarno Hatta Airport.

3. April 18, 2017 Ministry of Religious Affairs also clarify, investigate, advocate, until mediation with the congregation. At the same meeting, Kemenag immediately asked the clarity of the case to the First Travel officials. However, the management did not give any answers at all.

4. May 24, 2017 Kemenag again called First Travel on May 24, 2017. This effort also failed because the management was not present.

5. July 21, 2017 The Financial Services Authority (OJK) Investigate Task Force Unit ordered PT First Anugerah Karya Wisata to stop selling its promo package due to indications of illegal investments and unlawful public fundraising. First Travel also never submits data that signed and not yet dispatched. This document has been requested for four months. 
6. August 3, 2017 Revocation of permit is done because PT First Anugerah Karya Wisata is considered proven to have committed a violation. The violation is a neglect of Umrah pilgrims who failed to leave for Saudi Arabia and resulted in the loss of material and immaterial in Ummah congregation (Ratnawati, 2018).

Problems that occur

1. Conduct abandonment of prospective pilgrims so that more victims who fail to depart.

2. Provide promos that are not in line with government directives such as the 14 million umroh package.

3. Using one pilgrim's money to dispatch another pilgrim, so that in August there are 58,000 prospective pilgrims who fail to depart.

4. Umroh travel agents have permits, but their marketing activities are out of proportion and more likely to use MLM mechanisms (Putra, 2015)

After the First Travel fraud case, now Abu Tours. Tens of thousands of worshipers are victims. Both failed to leave umroh, until the money lost cannot come back. The estimated losses are not just billions but trillions. Although the victims are already tens of thousands and the losses reach trillions, I look at this case is not taken seriously. Either by the public or the government itself. Unheard of how the asset pursuit for money back and pilgrims' anticipation efforts ahead (Afrila, 2016).

There are indeed one, two, and three or fewer people who are arrested and processed to court, but about the loss, the disappearance of money, how the money is returned and its anticipation in the future has never been a concern.Fraud and money laundering under the guise of travel umroh. This if left untouched not only hundreds of thousands of pilgrims who could be victims, trillions of money that disappeared, also travel umroh others who run this pilgrimage services will be well affected. And the end is the public trust in the government (Ruswanda \& Bambang Eko Turisno, 2016).

Remember, the trillions of money are mostly Indonesian pilgrims collected little by little, even all the hard work throughout life is there (fried sellers are saving for umroh, motorcycle taxi drivers, farmers who harvest years of crops, etc.). The case of Abu Tours, which he said has collected more than Rp 1 trillion in pilgrimage money, but since this case has been investigated, the account in the owner is empty! (detikcom, 23-3). Similarly, the case of First Travel which total collected funds from the pilgrims USD 800 billion more, but in the account, owner is only Rp 2 million.

For the legal mafia network in Indonesia, the number of frauds First Travel and Abu Tours lucrative, let alone they patgulipat case. Successfully cheated by earning Rp 1 trillion, count the "cost of the case" and "live in prison" (which is often convicted low) totaling Rp 200 billion. There's still Rp 800 billion! Does not it make sense that First Travel and Abu Tours style scams are a planned crime? 
They were never business intention umroh, but since the beginning did want to collect money by cheating wearing mask travel umroh. Despite the case, to be caught and in prison, money from fraud is still abundant. What is worried, if this case is not addressed seriously and anticipation in the future, not only will emerge new players, but also travel-travel that has been working professionally could be "tempted". Shortcuts are rich quick, though they have to go to a lengthy prison. Because hard work and honest all life is considered will never be able to profit hundreds of billions. Procedural law enforcement is not enough to address cases of fraud such as First Travel and Abou Tours is because this case is soughtafter law mafia.

\section{LEGAL SETTLEMENT EFFORTS FIRST TRAVEL AND ABU TOUR \& TRAVEL}

As a limited liability company, First Travel and Abu Travel is a legal entity, therefore because First Travel as a legal entity they have a right and obligation of legal liability for alleged criminal acts committed to prospective pilgrims' worship Umrah, so that there should be responsibility relating to the concept of legal obligations and responsibilities (Ning Tyas Sari, 2015).

Legally if a person performs a liability responsibility for an act of a criminal nature or that he or she is liable for legal action will be liable for sanctions in the event of an occurrence of a thing contrary to law. In terms of legal aspects, legal responsibility in the first journey can be seen from the civil, criminal, and administrative aspects. From the civil aspect, First Trave and Abu Travel 1 have made a misconduct of not commissioning Umrah pilgrims, as well as having committed illegal acts (onrechmatige daad in Dutch and Tort in English). Therefore, First Travel can be sued in a civil manner to meet the engagement of dispatching candidates for Umrah pilgrims to the holy land. Fulfillment of this obligation should not be done alone by First Travel because the First Travel operational permit as the organizer of Umrah worship has been revoked by the Ministry of Religious Affairs. Fulfillment of First Travel obligations can be held by other Umrah Travel Bureaus, but at the cost of First Travel. Alternatively, First Travel may be charged with the cancellation of the engagement to return the money already paid by the prospective Umrah pilgrim to leave for the holy land. Related to the civil liability, the Panel of Judges of the Suspension of Debt Payment Obligation (PKPU) (Amalia, 2018).

The Central Jakarta District Court ruled First Travel and Abu Travel had debts to the plaintiff and granted the PKPU lawsuit from 3 First Travel customers. The three customers are Hendarsih, Ananda Perdana Saleh, and Euis Hilda Ria. Based on Article 225 paragraph (3) and paragraph (4) of Law no. 37 of 2004 concerning Bankruptcy and Postponement of Obligation of Debt Payment, the Assembly considers the application of PKPU to be granted. With the granting of 
PKPU, First Travel is declared "alive" and can be held accountable to civilian to dispatch candidate for Umrah or return Umrah's fee (Maggalatung, 2017).

From the criminal aspect, criminal liability can be requested to First Travel as judged to have made a mistake. Mistakes are very important to convict someone because in the criminal law is known the principle of "no crime without error (geen straf zonder schuld)". Related to this, there are some mistakes or criminal acts allegedly committed by First Travel, namely the criminal act of embezzlement (Article 372 of the Criminal Code). The criminal act of fraud (Article 378 of the Criminal Code). Actions money laundering (Law No. 8 of 2010 on Prevention and Eradication of Money Laundering Crime). PPATK suspects that the funds belonging to the prospective Umrah First Umrah pilgrims and Abu Travel in addition to being used to dispatch candidates for Umrah pilgrims, also used the suspects to buy assets for personal gain (Prabowo, 2016).

From the administrative aspect, administrative liability has been imposed on First Travel for violating policy or administrative law provisions. First Travel has been subject to administrative sanctions in the form of revocation of operational permit by Kemenag RI. With the revocation of the permit, First Travel and Abu Travel cannot hold umrah worship again. Minister of Religious Affairs Lukman Hakim Saifuddin affirmed that the travel agent company First First of Tourism is still obliged to dispatch the Umrah pilgrims that had been scheduled before. First Travel can use other Umrah travel agencies to dispatch their Umrah congregation. However, the Minister of Religious Affairs Mr. Lukman did not inform him about the procedure and time of transfer of First Travel congregation to other Umrah travel agencies. So, his permission is revoked and the revocation of this permit does not eliminate their obligation for two things. The first is a dispatch that has not departed through another travel agency. Both refund refund funds that have been deposited by the Umrah pilgrims and to those who are entitled if they decide not to leave umroh.

The revocation of the permit was since the sale of Umrah First Travel promo was troubling all the people. First Travel always break the promise to dispatch pilgrims. Previously the Ministry of Religious Affairs (Kemenag) revoked the permit for the pilgrimage of PT First Anugerah Karya Wisata (First Travel) and Abu Travel. Revocation of First Travel and Abu Travel permit is stated in Ministerial Decree of the Minister of Religious Affairs Number 589 Year 2017 concerning Sanction of Administration Sanction Revocation of License to Operate PT First Anugerah Karya Wisata as the Implementation of Umrah Worship Tour the Ministerial Decree has been effective since August 1, 2017. The Ministry of Religious Affairs (MoF) travel agent PT First Anugerah Karya Wisata (First Travel) and Abu Travel is obliged to refund the funds already paid. although his license has been revoked, that does not mean eliminating First Travel's obligations to his congregation. They are still obliged to return the entire cost of Umrah pilgrims who have registered or delegated all Umrah pilgrims who have registered to other PPIU without adding any cost. First Travel has violated Article 
65 letter a Government Regulation Number 79 Year 2012 on Implementation of Law Number 13 Year 2008 regarding Hajj Implementation. The violation is a neglect of Umrah pilgrims who failed to leave for Saudi Arabia and resulted in material and immaterial losses experienced by Umrah congregation. Chaotic umrah administration by First Travel began to rise when the failure of the departure of pilgrims on March 28, 2017, ago. In the event pilgrims lodged in the hotel around Soekarno Hatta Airport. Since then, Kemenag has been clarifying, investigating, advocating, and mediating with the congregation. The first clarification effort was made on April 18, 2017, but the management did not provide an answer. In addition, at least four attempts have been made between the congregation and First Travel. However, these efforts are not fruitful results because the First Travel party to be closed and less cooperative. The House of Representatives has a very important role in solving the case of First Travel and Abu Travel such as receiving complaints from the victims of prospective Umrah pilgrims. In order to carry out the oversight function, DPR RI (Commission XI DPR RI) has also highlighted the role of the Major Financial Services Authority (OJK) in the First Travel case. OJK is considered a bit slow in supervising and late in detecting First Travel practices. In addition, the House of Representatives has also encouraged the government and law enforcement agencies to immediately process and resolve the case of First Travel and Abu Travel. Vice Chairman of Commission VIII DPR RI Sodik Mudjahid, asked the police to confiscate all assets of First Travel and sell it so that it can be used to return the money for the Umrah pilgrims or to send Umrah to the holy land (Septrina, 2017).

\section{CONCLUSION}

The form of supervision by the government on the implementation of umrah based on the prevailing laws and regulations in Indonesia in the supervision and control of the implementation of umrah is one of the duties of the Ministry of Religious Affairs in accordance with Regulation of the Minister of Religious Affairs Number 18 of 2015 Article 20 Paragraph (1) and Paragraph (2) it is mentioned that Supervision 32 is conducted by the Director General on behalf of the Minister. Supervision includes supervision of travel plans, operational activities of Jemaah service, obedience and / or discipline to the provisions of legislation. In order to improve the supervision function of the service to Jemaah Umrah, the Ministry of Religious Affairs through the Directorate General of Hajj and Umrah Implementation regularly conduct monitoring at Soekarno Hatta airport. Every day assigned personnel from the Ministry of Religious Affairs with Airport Police to directly supervise Jemaah service activities at the airport. MoU Kemenag with Polri has been running since 2013 and always give full support.

Improving the supervision of umrah. Supervision is done because of the many travel agencies that provide services Umrah in Indonesia, currently the 
government is more focused on the implementation of the pilgrimage so that hand over the Umrah through travel agency. Meanwhile, the ministry of religion is only authorized to grant business licenses. As for the factors that led to weak supervision by the ministry of religion against the implementation of umroh worship in relation to the case of PT. The first grace of the tour is the Umroh Travel Permit, and rules that have not been able to satisfy consumer protection.

As for the efforts made by the ministry of religion to increase supervision over the efforts of umroh religious travel agency in order to protect the pilgrims. With its form as a limited liability company, First Travel is a legal entity, therefore a legal subject having rights and obligations. As a legal subject, First Travel has a legal liability for alleged criminal acts committed against prospective pilgrims and Umrah, responsibilities relating to the concept of legal obligations. A person is legally responsible for a particular act or that he or she assumes legal liability means that he is responsible for a sanction in the event of a conflicting action. From legal aspect, First Travel's legal responsibility can be seen from civil, criminal, and administrative aspects.

\section{REFERENCES}

Afrila, N. (2016). Analisis Yuridis Tanggung Jawab Perusahaan Penyelenggara Ibadah Umroh Terhadap Jamaahnya (Studi Pada PT. Makkah Wal Madinah Tour Cabang Medan). Premise Law Journal, 6, 161887. https://jurnal.usu.ac.id/index.php/premise/article/view/15745

Amalia, L. R. (2018). Perlindungan Hukum Konsumen Jasa Akibat Pembatalan Keberangkatan Jamaah Umroh Berdasarkan Undang-undang Perlindungan Konsumen, Undergraduate Thesis, Universitas 17 Agustus 1945.

Anggrianto, R. (2002). Resolusi Gila Bisnis Tour dan Travel. Jakarta: PT. Elex Media Komputindo.

Arifin, Z., Wahyuningsih, S. E., \& Kusriyah, S. (2017). Proses Penegakan Hukum

Terhadap Pelaku Tindak Pidana Penipuan Dan Atau Penggelapan Berkedok Biro Jasa Ibadah Umroh Dengan Biaya Murah (Studi Kasus Pada Penyidik Sat Reskrim Polrestabes Semarang). Jurnal Hukum Khaira Ummah, 12(4), 777784.

Maggalatung, S. (2017). Legal Protection Against Indonesian Umrah Jemaah. Jurnal Cita Hukum, 5(1), 171-182.

Miru, A., \& Yudo, S. (2015). Hukum Perlindungan Konsumen. Jakarta: PT. Raja Grafindo Persada.

Muhammad, A. (2004). Metode Penelitian Hukum. Jakarta: Sinar Grafika.

Ning Tyas Sari, A. (2015). Pertanggungjawaban Hukum Terhadap Pelaksanaan Perjanjian Pemberangkatan Ibadah Haji antara Biro Penyelenggara Ibadah Haji Khusus dengan Calon Jamaah Haji Plus (Studi Kasus di PT. Nur 
Ramadhan Wisata Cabang Yogyakarta. Undergraduate Thesis, Surakarta: Universitas Muhammadiyah Surakarta.

Prabowo, M. S. (2016). Perlindungan Hukum Jama'ah Haji Indonesia dalam Perspektif Perlindungan Konsumen. JURNAL LITIGASI (e-Journal), 15(1), 2093-2133. http://dx.doi.org/10.23969/litigasi.v15i1.72

Putra, A. P. (2018). Pengawasan Terhadap Penyelenggaraan Perjalanan Ibadah Umrah (Studi Terhadap Kasus PT. First Anugrah Karya Wisata). Jurnal Nestor Magister Hukum, 2(2).

Ratnawati, N. (2018). Upaya Penanggulangan Terjadinya Penipuan Yang Dilakukan Biro Perjalanan Umroh (Studi Kasus Kota Bandar Lampung). Undergraduate Thesis. Lampung: Universitas Lampung.

Rokhmad, A. (2016). Manajemen Haji Membangun Tata Kelola Haji Indonesia. Jakarta: Media Dakwah.

Ruswandana, N. V., \& Bambang Eko Turisno, S. (2016). Perlindungan Hukum Terhadap Konsumen dalam Pembatalan Keberangkatan Ibadah Haji Khusus oleh Biro Penyelenggara Ibadah Haji Khusus. Diponegoro Law Journal, 5(3), 1-12.

Salim, H. S. (2004). Perkembangan Hukum Jaminan di Indonesia. Jakarta: PT Raja Grafindo Persada.

Septrina, B. (2017). Penegakan Hukum Terhadap Pelaku Tindak Pidana Penipuan Calon Jamaah Umrah Pada Tahap Penyidikan (Studi Kasus di Polresta Bandar Lampung). Undergraduate Thesis, Lampung: Universitas Lampung.

Widjaya, I. G. R. (2008). Merancang Suatu Kontrak Contract Drafting Teori dan Praktik. Jakarta: Kesaint Blanc. 